\title{
Endocrine Late Effects of Childhood Cancer Therapy: A Report from the Children's Oncology Group
}

\author{
Radha Nandagopal $^{a} \quad$ Caroline Laverdière $^{b} \quad$ Daniel Mulrooney $^{c}$ \\ Melissa M. Hudson ${ }^{d}$ Lillian Meacham ${ }^{a}$ \\ aDivision of Pediatric Endocrinology, Department of Pediatrics, Emory University School of Medicine, \\ Atlanta, Ga., USA; bervice of Hematology/Oncology, Sainte-Justine Hospital, University of Montreal, \\ Montreal, Que., Canada; 'Division of Pediatric Hematology/Oncology/Blood and Marrow Transplantation, \\ Department of Pediatrics, University of Minnesota, Minnesota, Minn., and d Department of Hematology-Oncology, \\ St. Jude Children's Research Hospital and the University of Tennessee College of Medicine, Memphis, Tenn., USA
}

\section{Key Words \\ Endocrine late effects · Childhood cancer • Chemotherapy • Radiation therapy • Pediatrics}

\begin{abstract}
Pediatric oncologists are curing increasing numbers of patients with childhood cancer, and most children diagnosed with a malignancy may now be expected to become longterm survivors. As the number of childhood cancer survivors grows, so too does the need for evidence-based surveillance of the long-term effects of cancer therapy. Long-term effects involving the endocrine system represent a frequent complication of therapy. The Children's Oncology Group Long-Term Follow-Up Guidelines for Survivors of Childhood, Adolescent, and Young Adult Cancers (COG LTFUG), most recently updated in 2006, provide a summary of the known endocrine late effects of surgery, radiation, chemotherapy, and stem cell transplant. This paper summarizes the scope and nature of the endocrine late effects of childhood cancer therapy based upon a review of the pertinent medical literature, and demonstrates how pediatric oncologists can use these guidelines in clinical practice.
\end{abstract}

Copyright $\odot 2007$ S. Karger AG, Basel (c) 2007 S. Karger AG, Basel

0301-0163/08/0692-0065\$24.50/0

Fax +41613061234

E-Mail karger@karger.ch

www.karger.com
Accessible online at:

www.karger.com/hre

\section{Introduction}

One of the most significant advances of modern medicine has been the ability to treat childhood cancer effectively. Pediatric oncologists are curing increasing numbers of children, and today most children diagnosed with a malignancy are expected to become long-term cancer survivors. The 5 -year cure rate for childhood cancer is now nearly $80 \%$ [1], and for some cancers, such as acute lymphoblastic leukemia and Hodgkin's disease, cure rates exceed $90 \%[2,3]$. As the number of childhood cancer survivors grows, so too does the need for evidencebased surveillance of the long-term effects of cancer therapy. Nearly two-thirds of all of childhood cancer survivors will suffer some late effect, and the endocrine system is commonly involved $[4,5]$. Care of the childhood cancer survivor is shifting from merely the detection of relapse to an improved understanding of the long-term sequelae of cancer treatment.

Because of the continued refinement of childhood cancer therapy, the study of late effects is an ongoing process. New agents, varying doses, and treatment schedules are frequently being developed and tested through national therapeutic protocols. Therefore, the scope of cancer late effects is likely to continue to change over time.

Radha Nandagopal, MD

c/o Children's Oncology Group, Publications Office

440 E. Huntington Drive, 4th Floor

Arcadia, CA 91006 (USA)

Tel. +1 626241 1509, Fax +1 626445 4334, E-Mail rnandagopal@hotmail.com 
Table 1. Categories of consensus scoring for the COG long-term follow-up guidelines

\section{Cate- Statement of consensus}

gory

1 There is uniform consensus of the panel that: (1) there is high-level evidence linking the late effect with the therapeutic exposure and (2) the screening recommendation is appropriate based on the collective clinical experience of panel members

2A There is uniform consensus of the panel that (1) there is lower-level evidence linking the late effect with the therapeutic exposure and (2) the screening recommendation is appropriate based on the collective clinical experience of panel members

2B There is non-uniform consensus of the panel that (1) there is lower-level evidence linking the late effect with the therapeutic exposure and (2) the screening recommendation is appropriate based on the collective clinical experience of panel members

3 There is major disagreement that the recommendation is appropriate

Uniform consensus: Near-unanimous agreement of the panel with some possible neutral positions.

Non-uniform consensus: The majority of panel members agree with the recommendation; however, there is recognition among panel members that, given the quality of evidence, clinicians may choose to adopt different approaches.

High-level evidence: Evidence derived from high-quality case control or cohort studies.

Lower-level evidence: Evidence derived from non-analytic studies, case reports, case series, and clinical experience.

As many as $40 \%$ of childhood cancer survivors may have endocrine disturbances related to their underlying malignancy, surgery, radiation therapy (RT), or chemotherapy $[4,6]$. These factors are further modified by the age at which treatment was initiated, the length of time since treatment, and gender [3, 7]. Many cancer centers have comprehensive, long-term follow-up clinics where interdisciplinary teams screen for late effects based upon published guidelines [8]. These clinics are frequently a source of referrals to pediatric endocrinologists. Given the rising survivorship rates and increasing prevalence of endocrine late effects, pediatric endocrinologists must be prepared to see childhood cancer survivors. The field of endocrine-related late effects is growing and producing a burgeoning body of research, with which pediatric endocrinologists should become familiar.
The purpose of this mini review is to provide an overview of the scope and nature of the endocrine late effects of childhood cancer therapy. We will outline the screening currently recommended by the Children's Oncology Group Long-Term Follow-Up Guidelines for Survivors of Childhood, Adolescent, and Young Adult Cancers (COG LTFUG) and provide a summary of the known endocrine late effects of RT, chemotherapy, and hematopoietic cell transplant (HCT). Additionally, we will demonstrate how oncologists approach the detection of late effects and the point at which endocrinology consultation is recommended.

\section{COG Long-Term Follow-Up Guidelines}

The COG LTFUG offer guidance for clinical screening for a wide array of late effects that can result from the therapies used to treat pediatric malignancies. The COG LTFUG are agent/modality-specific, and subdivided into the following categories: chemotherapy, RT, surgery, $\mathrm{HCT}$, and cancer screening. Initial review of the published medical literature resulted in the development of the first version of the COG LTFUG [9]. Before release, the COG LTFUG were extensively reviewed and scored by a panel of experts using a modified version of the National Comprehensive Cancer Network 'Categories of Consensus' system (table 1). Each score reflects the strength of data from the literature linking a specific late effect with a therapeutic exposure, coupled with an assessment of the appropriateness of the screening recommendation based on the collective experience of the expert panel, matching the magnitude of the risk of developing the complication with the intensity of the recommended screening. Multidisciplinary system-based task forces organized within the COG Late Effects Committee are responsible for monitoring the literature, evaluating guideline content, and providing recommendations for guideline revision as new information becomes available. The Guidelines Task Force on Endocrine and Metabolic Complications includes 5 pediatric endocrinologists, 3 pediatric oncologists, 1 pediatric radiation oncologist, 1 primary care physician, 3 pediatric oncology nurses, and 1 patient advocate. Task force recommendations for guideline revisions are presented to the Late Effects Steering Committee for approval and scoring before incorporation into the COG LTFUG. Version 2.0, the most recent update of the COG LTFUG and accompanying health education materials are available at www.survivorshipguidelines.org.
66

Horm Res 2008;69:65-74
Nandagopal/Laverdière/Mulrooney/ Hudson/Meacham 
Table 2. Endocrine late effects of childhood cancer therapy: COG LTFUG

\begin{tabular}{|c|c|c|c|c|c|c|c|c|c|c|c|c|}
\hline & $\begin{array}{l}\text { GH } \\
\text { defi- } \\
\text { ciency }\end{array}$ & $\begin{array}{l}\text { Hypo- } \\
\text { thyroid- } \\
\text { ism }\end{array}$ & $\begin{array}{l}\text { Hyper- } \\
\text { thyroid- } \\
\text { ism }\end{array}$ & $\begin{array}{l}\text { Thyroid } \\
\text { nodule/ } \\
\text { cancer }\end{array}$ & $\begin{array}{l}\text { Central } \\
\text { adrenal } \\
\text { insufficiency }\end{array}$ & $\begin{array}{l}\text { Preco- } \\
\text { cious } \\
\text { puberty }\end{array}$ & $\begin{array}{l}\text { Hypo- } \\
\text { gonad- } \\
\text { ism }\end{array}$ & $\begin{array}{l}\text { Infer- } \\
\text { tility }\end{array}$ & $\begin{array}{l}\text { Low bone } \\
\text { mineral } \\
\text { density }\end{array}$ & $\begin{array}{l}\text { Obesity/ } \\
\text { hyper- } \\
\text { lipidemia }\end{array}$ & $\begin{array}{l}\text { Metab- } \\
\text { olic syn- } \\
\text { drome }\end{array}$ & $\begin{array}{l}\text { Hyper } \\
\text { prolac- } \\
\text { tinemia }\end{array}$ \\
\hline Cranial irradiation $^{1}$ & + & + & & + & + & + & + & + & & + & + & + \\
\hline Total body irradiation & + & + & & + & & & + & + & & & + & \\
\hline \multicolumn{13}{|l|}{ Target organ irradiation } \\
\hline Thyroid ${ }^{2}$ & & + & + & + & & & & & & & & \\
\hline Gonadal $^{3}$ & & & & & & & + & + & & & & \\
\hline \multicolumn{13}{|l|}{ Alkylating agents } \\
\hline Non-classical & & & & & & & + & + & & & & \\
\hline Alkylators & & & & & & & + & + & & & & \\
\hline \multicolumn{13}{|l|}{ Anthracyclines } \\
\hline Heavy metals & & & & & & & + & + & & $\begin{array}{l}\text { + Dys- } \\
\text { lipidemia }\end{array}$ & & \\
\hline Antimetabolites & & & & & & & & & + & & & \\
\hline \multicolumn{13}{|l|}{ Antitumor antibiotics } \\
\hline Corticosteroids & & & & & & & & & + & & & \\
\hline \multicolumn{13}{|l|}{ Enzymes } \\
\hline \multicolumn{13}{|l|}{ Plant alkaloids } \\
\hline \multicolumn{13}{|l|}{ Epipodophyllotoxins } \\
\hline \multicolumn{13}{|l|}{$\begin{array}{c}\text { Hematopoietic cell } \\
\text { transplantation }\end{array}$} \\
\hline $\begin{array}{l}{ }^{1} \text { Cranial irradiation } \\
{ }^{2} \text { Thyroid irradiatio } \\
{ }^{3} \text { Gonadal radiation }\end{array}$ & $\begin{array}{l}\text { udes: c } \\
\text { ludes: } \\
\text { ades: lu }\end{array}$ & $\begin{array}{l}\text { ranial, or } \\
\text { hyroid, } \mathrm{n} \\
\text { mbosacr }\end{array}$ & $\begin{array}{l}\text { bital/eye } \\
\text { leck, cer } \\
\text { al spine, }\end{array}$ & $\begin{array}{l}\text { ear/infr } \\
\text { ical spin } \\
\text { abdomen }\end{array}$ & $\begin{array}{l}\text { atemporal an } \\
\text { e, oropharyn } \\
\text { and pelvis ( } \mathrm{f}\end{array}$ & $\begin{array}{l}\text { d nasop } \\
\text { geal, sup } \\
\text { females) }\end{array}$ & $\begin{array}{l}\text { harynge } \\
\text { raclavic } \\
\text { and pely }\end{array}$ & $\begin{array}{l}\text { al. } \\
\text { ular, } \mathrm{m} \\
\text { is and }\end{array}$ & $\begin{array}{l}\text { hantle and } \\
\text { testicular }\end{array}$ & $\begin{array}{l}\text { mini mar } \\
\text { (males). }\end{array}$ & ntle. & \\
\hline
\end{tabular}

\section{Using the COG Long-Term Follow-Up Guidelines}

The COG LTFUG are intended to be used to evaluate patients who have survived at least 2 years beyond the date of completion of cancer therapy. To organize the appropriate risk-based evaluation, a medical summary should be created that includes information about the cancer histology, involved anatomic sites and all therapeutic agents/modalities received with cumulative doses of agents as appropriate. Using the COG LTFUG, this information is then used to identify the potential late effects for which the patient may be at risk (table 2). The COG LTFUG make recommendations for elements of the history and physical examination, laboratory and imaging studies that should be done to monitor for late effects and the frequency of such evaluations (table 3). Forty-two 'Health Links' are also available on the website that can be used to educate families and patients about specific late effects (table 4).

Endocrine Late Effects

\section{Cranial Radiation}

The impact of RT depends upon the involved field, total dose, and schedule [10]. There is a well-established association between the total radiation dose and the development of pituitary hormone deficiencies [11, 12]. The growth hormone $(\mathrm{GH})$ axis is the most sensitive of the hypothalamic functions to radiation and can be affected at doses of 18 Gy irradiation [13-15]. At hypothalamic doses of radiation $>40 \mathrm{~Gy}$, gonadotropin, corticotropin, and thyrotropin secretion may be compromised.

The age of the patient at the time of RT may affect the degree of hypothalamic-pituitary damage sustained. Some studies suggest that younger age at the time of diagnosis and treatment may lead to more deleterious effects on the hypothalamic-pituitary axis [10]. When a child who has undergone cranial RT presents for care, issues of growth, central hypothyroidism, central adrenal insufficiency, precocious puberty, gonadotropin deficiency, hyperprolactinemia, and obesity must all be considered.

Horm Res 2008;69:65-74 
Table 3. Proposed screening and monitoring for potential late effects based on the COG LTFUG, version 2

\begin{tabular}{|c|c|c|c|c|c|c|c|}
\hline Potential late effect & History & $\begin{array}{l}\text { History } \\
\text { fre- } \\
\text { quency }\end{array}$ & Physical & $\begin{array}{l}\text { Physical } \\
\text { frequency }\end{array}$ & $\begin{array}{l}\text { Laboratory } \\
\text { studies }\end{array}$ & $\begin{array}{l}\text { Labor- } \\
\text { atory } \\
\text { frequency }\end{array}$ & $\begin{array}{l}\text { Further considerations } \\
\text { when to refer }\end{array}$ \\
\hline Growth problems & Assess nutritional status & $\begin{array}{l}\text { Every } \\
6 \text { months }\end{array}$ & $\begin{array}{l}\text { Height and } \\
\text { weight BMI } \\
\text { Tanner staging }\end{array}$ & $\begin{array}{l}\text { Every } 6 \text { months } \\
\text { until growth } \\
\text { complete } \\
\text { Every } 6 \text { months } \\
\text { until sexually } \\
\text { mature }\end{array}$ & & & $\begin{array}{l}\text { If poorly growing - bone age } \\
\text { and thyroid labs } \\
\text { Refer to endocrine if } \\
\text { Height }<3 \text { rd percentile } \\
\text { Drop }>2 \text { percentile channels } \\
\text { Growth }<4-5 \mathrm{~cm} / \text { year } \\
\text { Lack of pubertal growth spurt } \\
\text { If GH deficiency consider DEXA }\end{array}$ \\
\hline $\begin{array}{l}\text { Hypothyroidism } \\
\text { central and primary }\end{array}$ & $\begin{array}{l}\text { Fatigue, weight gain, } \\
\text { cold intolerance, } \\
\text { constipation, } \\
\text { dry skin, brittle hair, } \\
\text { depressed mood }\end{array}$ & Yearly & $\begin{array}{l}\text { Height and weight } \\
\text { Hair, skin } \\
\text { Thyroid exam }\end{array}$ & Yearly & $\begin{array}{l}\text { Free } \mathrm{T}_{4} \\
\text { TSH }\end{array}$ & Yearly & $\begin{array}{l}\text { Refer to endocrine for thyroid } \\
\text { hormone replacement }\end{array}$ \\
\hline Hyperthyroidism & $\begin{array}{l}\text { Heat intolerance, } \\
\text { tachycardia } \\
\text { Palpitations, weight loss } \\
\text { Emotional lability } \\
\text { Muscular weakness } \\
\text { Hyperphagia }\end{array}$ & Yearly & $\begin{array}{l}\text { Eyes, skin, } \\
\text { Thyroid } \\
\text { Cardiac } \\
\text { Neurologic }\end{array}$ & Yearly & $\begin{array}{l}\text { Free } \mathrm{T}_{4} \\
\mathrm{TSH}\end{array}$ & Yearly & $\begin{array}{l}\text { Refer to endocrine for } \\
\text { management of } \\
\text { hyperthyroidism }\end{array}$ \\
\hline Thyroid nodule & & & Thyroid exam & Yearly & & & $\begin{array}{l}\text { Ultrasound and FNA for nodule } \\
\text { Refer to endocrine and surgery } \\
\text { for biopsy and or thryoidectomy } \\
\text { Nuclear medicine for ablation } \\
\text { Refer to endocrine for postop. } \\
\text { management }\end{array}$ \\
\hline $\begin{array}{l}\text { Central adrenal } \\
\text { insufficiency }\end{array}$ & $\begin{array}{l}\text { Failure to thrive, anorexia } \\
\text { Dehydration, hypo- } \\
\text { glycemia } \\
\text { Lethargy unexplained } \\
\text { hypotension }\end{array}$ & Yearly & & & $\begin{array}{l}\text { 08:00 a.m. } \\
\text { Cortisol }\end{array}$ & $\begin{array}{l}\text { Yearly for } \\
15 \text { years }\end{array}$ & $\begin{array}{l}\text { Refer to endocrine for } \\
\text { replacement }\end{array}$ \\
\hline $\begin{array}{l}\text { Precocious } \\
\text { puberty }\end{array}$ & & & $\begin{array}{l}\text { Height and weight } \\
\text { Tanner stage } \\
\text { Testicular volume }\end{array}$ & $\begin{array}{l}\text { Yearly until } \\
\text { sexually } \\
\text { mature }\end{array}$ & $\begin{array}{l}\text { FSH } \\
\text { LH } \\
\text { Testosterone/ } \\
\text { Estradiol }\end{array}$ & $\begin{array}{l}\text { prn signs } \\
\text { of early } \\
\text { puberty }\end{array}$ & $\begin{array}{l}\text { If rapidly growing - bone age } \\
\text { Refer to endocrine if accelerated } \\
\text { puberty in } \\
\text { girls }<8 \text { years old } \\
\text { boys }<9 \text { years old }\end{array}$ \\
\hline $\begin{array}{l}\text { Gonadotropin } \\
\text { deficiency } \\
\text { Delayed puberty } \\
\text { Premature menopause } \\
\text { Infertility } \\
\text { Females }\end{array}$ & $\begin{array}{l}\text { Pubertal (onset, tempo) } \\
\text { Menstrual/pregnancy } \\
\text { history } \\
\text { Sexual function } \\
\text { (vaginal dryness, libido) } \\
\text { Medication use impacting } \\
\text { sexual function }\end{array}$ & Yearly & Tanner stage & $\begin{array}{l}\text { Yearly until } \\
\text { sexually } \\
\text { mature }\end{array}$ & $\begin{array}{l}\text { FSH } \\
\text { LH } \\
\text { Estradiol }\end{array}$ & $\begin{array}{l}\text { Begin } \\
@ 13 \text { and } \\
\text { prn }\end{array}$ & $\begin{array}{l}\text { Consider DEXA } \\
\text { Refer to endocrine if } \\
\text { Delayed puberty } \\
\text { Persistently abnormal labs } \\
\text { Refer to reproductive endocrine } \\
\text { for Infertility }\end{array}$ \\
\hline $\begin{array}{l}\text { Gonadotropin } \\
\text { deficiency } \\
\text { Delayed puberty } \\
\text { Infertility }\end{array}$ & $\begin{array}{l}\text { Pubertal (onset, tempo) } \\
\text { Sexual function } \\
\text { (erections, nocturnal } \\
\text { emissions, libido) }\end{array}$ & Yearly & $\begin{array}{l}\text { Tanner stage } \\
\text { Testicular volume }\end{array}$ & $\begin{array}{l}\text { Yearly until } \\
\text { sexually } \\
\text { mature }\end{array}$ & $\begin{array}{l}\text { FSH } \\
\text { LH } \\
\text { Testosterone }\end{array}$ & $\begin{array}{l}\text { Begin } \\
\text { @ } 14 \text { and } \\
\text { prn }\end{array}$ & $\begin{array}{l}\text { Consider DEXA } \\
\text { Refer to endocrine if } \\
\text { Delayed or arrested puberty } \\
\text { Persistently abnormal labs } \\
\text { Refer to reproductive endocrine } \\
\text { for infertility } \\
\text { consider inhibin B }\end{array}$ \\
\hline $\begin{array}{l}\text { Hyper- } \\
\text { prolactinemia }\end{array}$ & $\begin{array}{l}\text { Galactorrhea } \\
\text { Decreased libido (males) } \\
\text { Menstrual history } \\
\text { (females) }\end{array}$ & Yearly & & & Prolactin & prn & $\begin{array}{l}\text { Consider CT of the sella } \\
\text { Refer to endocrine if } \\
\text { hyperprolactinemia, } \\
\text { galactorrhea or amenorrhea }\end{array}$ \\
\hline
\end{tabular}


Table 3 (continued)

\begin{tabular}{|c|c|c|c|c|c|c|c|}
\hline Potential late effect & History & $\begin{array}{l}\text { History } \\
\text { fre- } \\
\text { quency }\end{array}$ & Physical & $\begin{array}{l}\text { Physical } \\
\text { frequency }\end{array}$ & $\begin{array}{l}\text { Laboratory } \\
\text { studies }\end{array}$ & $\begin{array}{l}\text { Labor- } \\
\text { atory } \\
\text { frequency }\end{array}$ & $\begin{array}{l}\text { Further considerations } \\
\text { when to refer }\end{array}$ \\
\hline $\begin{array}{l}\text { Low bone mineral } \\
\text { density }\end{array}$ & & & & & $\begin{array}{l}\text { Bone density } \\
\text { evaluation } \\
\text { DEXA or } \\
\text { quantitative CT }\end{array}$ & Baseline $^{1}$ & $\begin{array}{l}\text { Refer to endocrine } \\
\text { if osteoporosis T score } \geq 2.5 \text { DS } \\
\text { or history of multiple fractures }\end{array}$ \\
\hline $\begin{array}{l}\text { Overweight } \\
\text { Age 2-20 } \\
\text { BMI }>85-95 \text { th \%tile } \\
\text { Age }>21 \\
\text { BMI 25-29.9 } \\
\text { Obese } \\
\text { Age 2-20 } \\
\text { BMI } \geq 95 \text { th \%tile } \\
\text { Age }>21 \\
\text { BMI }>30\end{array}$ & & & $\begin{array}{l}\text { Height and } \\
\text { weight } \\
\text { BMI } \\
\text { BP }\end{array}$ & Yearly & $\begin{array}{l}\text { Fasting blood } \\
\text { glucose } \\
\text { Fasting serum } \\
\text { insulin } \\
\text { Fasting lipid } \\
\text { profile }\end{array}$ & $\begin{array}{l}\text { Every } \\
2 \text { years if } \\
\text { overweight } \\
\text { Every } \\
5 \text { years if } \\
\text { normal } \\
\text { weight }\end{array}$ & $\begin{array}{l}\text { Evaluate for metabolic } \\
\text { syndrome } \\
\text { Refer to endocrine if hyper- } \\
\text { lipidemia or hyperglycemia }\end{array}$ \\
\hline Metabolic syndrome & & & $\begin{array}{l}\text { Height and } \\
\text { weight } \\
\text { BMI } \\
\text { BP }\end{array}$ & Yearly & $\begin{array}{l}\text { Fasting blood } \\
\text { glucose } \\
\text { Fasting serum } \\
\text { insulin } \\
\text { Fasting lipid } \\
\text { profile }\end{array}$ & $\begin{array}{l}\text { Every } \\
5 \text { years } \\
\text { and prn }\end{array}$ & $\begin{array}{l}\text { Refer to endocrine if insulin } \\
\text { resistance/metabolic syndrome }\end{array}$ \\
\hline Dyslipidemia & & & & & $\begin{array}{l}\text { Fasting lipid } \\
\text { profile }\end{array}$ & Baseline $^{1}$ & \\
\hline
\end{tabular}

${ }^{1}$ Baseline $=$ Entry into long term follow-up program.

\section{Growth Hormone Deficiency}

$\mathrm{GH}$ deficiency is the most common endocrine problem following cranial RT. Until growth is completed, the COG LTFUG recommend that children treated with cranial RT should undergo semi-annual screening for grow th failure by assessing nutritional status, and monitoring of height, weight, and BMI percentiles, as well as sexual maturity rating. Additional considerations include bone age and thyroid studies for poorly growing children. Endocrine consultation should be obtained for children who are below the third percentile for height or weight, have dropped two percentile channels on the growth chart, or are growing slower than $4-5 \mathrm{~cm}$ per year. Endocrinology input should also be sought in adults considering GH replacement therapy. Bone mineral density assessment should be considered for children who are GH-deficient (table 3).

\section{Precocious Puberty and Gonadotropin Deficiency}

Pubertal stage and maturation should also be assessed in survivors who have undergone cranial RT. True precocious puberty, early puberty, and normally-timed puberty with rapid progression have been associated with radiation doses of $\geq 18 \mathrm{~Gy}$; female gender and younger age at treatment are also risk factors [16, 17]. Radiation doses $>40$ Gy may delay puberty through gonadotropin deficiency $[10,18]$. The COG LTFUG screening recommendations include annual history (as appropriate) to include questions about pubertal onset and tempo, sexual function, menstrual and pregnancy history, Tanner staging and testicular volume assessment. Luteinizing hormone, folliclestimulating hormone, and estradiol or testosterone should be obtained if precocious puberty is suspected in girls $<8$ years and boys $<9$, as well as in all females at age 13 and all males at age 14 who are exposed to a therapy that could damage any part of the gonadal axis. Semen analysis could be obtained as requested by at-risk male patients. As has been demonstrated in populations without cancer, cigarette smoking can also adversely impact fertility.

Additional considerations include bone age and endocrine consultation if precocious puberty is suspected. Endocrine consultation should be obtained for suspected delayed puberty or gonadal failure. Consultation with a reproductive specialist may be necessary. Bone mineral density assessment should be obtained in patients with gonadotropin deficiency. In addition, counseling is critical to address the possibility of infertility and premature 
Table 4. Health education materials available to patients and families at www.survivorshipguidelines.org

\begin{tabular}{|c|c|}
\hline $\begin{array}{l}\text { Endocrine-related } \\
\text { health links }\end{array}$ & Relevant cancer therapy \\
\hline $\begin{array}{l}\text { Diet and physical } \\
\text { activity }\end{array}$ & All survivors of pediatric cancer \\
\hline GH deficiency & Total body irradiation, cranial radiation ${ }^{1}$ \\
\hline $\begin{array}{l}\text { Central adrenal } \\
\text { insufficiency }\end{array}$ & Cranial radiation $^{1}$ \\
\hline Hyperprolactinemia & Cranial radiation $^{1}$ \\
\hline Hypopituitarism & Total body irradiation, cranial radiation ${ }^{1}$ \\
\hline Thyroid problems & $\begin{array}{l}\text { Total body irradiation, cranial radiation } \\
\text { radiation that includes the thyroid }^{2}\end{array}$ \\
\hline Female health issues & $\begin{array}{l}\text { Total body irradiation, cranial radiation }{ }^{1} \text {, } \\
\text { gonadal radiation }{ }^{3} \text {, alkylating agents, } \\
\text { heavy metals }\end{array}$ \\
\hline Male health issues & $\begin{array}{l}\text { Total body irradiation, cranial radiation }{ }^{1} \text {, } \\
\text { gonadal radiation }{ }^{3} \text {, alkylating agents, } \\
\text { heavy metals }\end{array}$ \\
\hline Precocious puberty & Cranial radiation ${ }^{1}$ \\
\hline Bone health & $\begin{array}{l}\text { Antimetabolites, corticosteroids, } \\
\text { hematopoietic cell transplantation }\end{array}$ \\
\hline \multicolumn{2}{|c|}{$\begin{array}{l}{ }^{1} \text { Cranial irradiation includes: cranial, orbital/eye, ear/infra- } \\
\text { temporal and nasopharyngeal. } \\
{ }^{2} \text { Thyroid irradiation includes: thyroid, neck, cervical spine } \\
\text { oropharyngeal, supraclavicular, mantle and mini mantle. } \\
{ }^{3} \text { Gonadal radiation includes: lumbosacral spine, abdomer } \\
\text { and pelvis (females) and pelvis and testicular (males). }\end{array}$} \\
\hline
\end{tabular}

menopause, but at the same time the need for contraception, since recovery of fertility has been reported years after completion of cancer therapy.

\section{Central Hypothyroidism}

Central hypothyroidism in the setting of cranial RT is primarily the result of deficiencies of thyrotropin-releasing hormone (hypothalamic) and thyroid-stimulating hormone (pituitary) in children who have received $>40$ Gy of radiation $[19,20]$. The COG LTFUG recommendations for annual screening include a focused history for symptoms of hypothyroidism, height, weight, skin, hair and thyroid examination, and a free $\mathrm{T}_{4}$ and TSH. Additional considerations include referral to endocrinology for management of hypothyroidism, especially during pregnancy and if attempting to become pregnant.

\section{Central Adrenal Insufficiency}

Cranial RT may also give rise to central adrenal insufficiency. At radiation doses $>40$ Gy, the adrenal corticotropin hormone (ACTH) axis may be affected to varying degrees [21, 22]. The COG LTFUG recommend annual screening to include: a focused history with an assessment for failure to thrive, anorexia, dehydration, hypoglycemia, lethargy, and unexplained hypotension, and an 08:00 a.m. cortisol level. Because central adrenal insufficiency has been identified in survivors many years after the completion of therapy, an 08:00 a.m. serum cortisol level should be obtained yearly until 15 years off therapy $[21,23]$. Additional considerations include a referral to endocrinology if morning cortisol levels are $<10 \mu \mathrm{g} / \mathrm{dl}$, for further evaluation and treatment.

\section{Hyperprolactinemia}

High-dose cranial RT (>40 Gy), mid-brain surgery, or tumor in the hypothalamic area may predispose a child to the development of hyperprolactinemia, which interferes with the pulsatile secretion of gonadotropinreleasing hormone $[12,24]$. In the female, a history of galactorrhea and menstrual irregularities are of prime importance; in the male, the presence of galactorrhea and decreased libido warrant further evaluation. The COG LTFUG recommend a screening prolactin level in survivors with clinical signs and symptoms of prolactin excess. Additional considerations include imaging of the sella and referral to endocrine if the prolactin is elevated.

\section{Obesity/Metabolic Syndrome}

Cranial RT may also lead to weight management issues, often exacerbated by concurrent GH deficiency and hypothyroidism. Females, and children $<4$ years at the time of treatment, as well as those who have received hypothalamic radiation doses $>18$ Gy are at particular risk [25-27]. The COG LTFUG recommend annual assessment of blood pressure and body mass index. Fasting blood glucose, serum insulin, and lipid profile should be screened every 2 years in patients who are overweight or obese and every 5 years in normal weight patients. Additional considerations include the assessment of other co-morbid conditions including dyslipidemia, hypertension, glucose intolerance, diabetes mellitus, hyperinsulinism, and insulin resistance. Nutrition, endocrinology, and/or cardiology referrals may be necessary for the management of dyslipidemia, hyperglycemia and hyperinsulinemia. 


\section{Target-Organ Irradiation}

Apart from cranial irradiation, target-organ irradiation involving the neck, abdomen, pelvis, and testes has the most pronounced endocrine late effects.

\section{Thyroid Irradiation}

With radiation doses in excess of $10 \mathrm{~Gy}$ in the region of the thyroid, hypothyroidism or, rarely, hyperthyroidism may occur. Irradiation to the thyroid, especially at doses $>25 \mathrm{~Gy}$, may also predispose to the development of thyroid nodules; thus annual thyroid palpation is important during physical examination. Thyroid cancer may also develop after radiation to the neck. Recent evidence shows increasing risk with doses up to $30 \mathrm{~Gy}$ and then decreasing risk for thyroid cancer with higher doses of radiation [28]. The COG LTFUG recommend physical examination with particular attention to the thyroid gland, free $\mathrm{T}_{4}$, and TSH on an annual basis to screen for thyroid sequelae. Additional considerations include consultation with endocrinology for management of hypothyroidism, hyperthyroidism and evaluation of thyroid nodules/cancer for diagnostic biopsy, coordination of thyroidectomy, postoperative management, and radioablation, if indicated.

\section{Gonadal Radiation}

Total body irradiation (TBI), abdominal, pelvic and lumbosacral spine radiation, especially in the postpubertal female, can compromise ovarian function. Mounting evidence suggests increased risk for premature menopause that must be factored into the long-term counseling of young adult survivors [29]. Women at highest risk include pubertal females treated with $\geq 10 \mathrm{~Gy}$, and those who have received high doses of alkylating agents (see Chemotherapy section).

The testes are particularly sensitive to radiation, with germ cells suffering damage at much lower levels of radiation than Leydig cells [30-32]. The effect of testicular irradiation is highly dose-dependent. At doses of 1-3 Gy, azoospermia may be reversible; at 3-6 Gy, this reversibility is much less likely. Over $6 \mathrm{~Gy}$, the patient is likely to suffer from permanent azoospermia. Doses >20 Gy may cause Leydig cell damage and affect production of testosterone. Please see the gonadal sections under cranial radiation for surveillance recommendations from the $C O G$ LTFUG.

\section{Total Body Irradiation}

The effects of TBI parallel those of cranial and craniospinal RT, with added effects on specific endocrine endorgans. It is also important to note that TBI and HST are most often utilized as salvage therapy after primary cancer therapy failure; therefore, the cumulative effects of aggressive use of multiagent cancer therapy with multifactorial endocrine dysfunction should be considered. Endocrine complications reported following TBI include GH deficiency, primary hypothyroidism, thyroid nodules/cancer, and primary hypogonadism [13, 29, 33]. Survivors treated with TBI also manifest an increased risk of the metabolic syndrome, which may occur in the absence of overweight/obesity [34]. The COG LTFUG screening evaluations for each endocrine system and recommendations for referrals have been discussed previously and are summarized in table 3.

\section{Chemotherapy}

Overall, the effects of chemotherapeutic agents on the endocrine system are less extensive than the effects of radiation. Nonetheless, the sequelae can be important and the COG LTFUG address the necessary screening. Gonadal dysfunction, dyslipidemia, and osteopenia/osteoporosis are the primary endocrine late effects observed following chemotherapy. We will address these in the context of each class of agent.

\section{Gonadal Dysfunction}

Alkylating agents, heavy metals, and non-classical alkylators cause dose-related male and female gonadal dysfunction. Some alkylating agents, such as busulfan, procarbazine, and mechlorethamine, are particularly gonadotoxic [35]. Cyclophosphamide is one of the most commonly used alkylating agents in treatment protocols for pediatric cancers; men treated with cumulative doses of cyclophosphamide $>7.5 \mathrm{~g} / \mathrm{m}^{2}$ are at highest risk of gonadal toxicity [36]. As with RT, germ cell function is impaired at lower doses than Leydig cell function [31, 37, 38]. In addition, the combination of chemotherapy with testicular, pelvic, or TBI significantly increases the risk of gonadal dysfunction [39]. Female gonadal dysfunction as a result of alkylating agents can result in delayed or arrested puberty, premature menopause, or infertility. High doses of alkylating agents, combinations of these agents, and combination with RT involving the neuroendocrine axis or ovarian region can all contribute to increased risk 
of gonadal dysfunction $[38,39]$. The COG LTFUG for screening for gonadal dysfunction and the additional considerations are as delineated above for gonadotropin deficiency following cranial radiation and are found in table 3 .

\section{Low Bone Mineral Density}

Low bone mineral density is an adverse effect observed following the use of antimetabolite agents (particularly methotrexate) and corticosteroids (prednisone and dexamethasone). Altered bone metabolism caused by cancer treatment may hinder the acquisition of peak bone mass and increase the risk of premature onset and more severe osteopenia later in life. The World Health Organization defines osteopenia for adults as bone mineral density $\geq 1$ and $<2.5 \mathrm{~T}$ scores (the number of standard deviations from the mean) below the mean, and osteoporosis is defined as bone mineral density $\geq 2.5 \mathrm{~T}$ scores below the mean. Recommendations for children are extrapolated from the WHO definition and $\mathrm{Z}$ scores are calculated based on age and gender. The risk of decreased bone mineral density is increased when methotrexate is used in conjunction with corticosteroids, or when prolonged courses of corticosteroids are required, as in treatment for graft-versus-host disease. Patients with concomitant GH deficiency, hypogonadism, hyperthyroidism, or who have high-risk behaviors such as smoking, alcohol use, lack of weight-bearing exercise, or low calcium intake are at increased risk for low bone mineral density. The COG LTFUG recommends a screening bone mineral density evaluation by dual energy X-ray absorptiometry scan or quantitative computed tomography at 2 years after completion of cancer therapy in at-risk survivors. Additional considerations include: calcium and vitamin D supplementation, optimization of endocrine replacements and referrals for children with multiple fractures or a history of very low BMD. While it is recognized that there are no definitive standards for the referral or treatment of low bone mineral density in children, the prevalence and severity of bone mineral deficits observed in specific groups of childhood cancer survivors suggest that monitoring and providing interventions to correct bone mineral deficits may be beneficial $[40,41]$.

\section{Dyslipidemia}

The heavy metals carboplatin and cisplatin may cause dyslipidemia. High-risk patients include those with a family history of lipid disorders and those who are overweight or obese, a state which may be exacerbated by GH deficiency. The recommended screening by the COG
LTFUG involves a baseline fasting lipid profile. Additional considerations include counseling for dietary modification, exercise and weight loss. Pharmacologic interventions should be considered in patients unresponsive to dietary and lifestyle modifications [42, 43].

Thus far, it appears that antitumor antibiotics such as anthracyclines (examples include daunorubicin and doxorubicin), bleomycin and dactinomycin have no apparent endocrine late effects. The same is true of enzymes (asparaginase), plant alkaloids (vincristine and vinblastine), and epipodophyllotoxins (etoposide and teniposide).

\section{Hematopoietic Cell Transplantation}

There is a growing body of research surrounding the late effects of stem cell transplantation [44]. A variety of endocrine late effects have been observed after transplant including gonadal dysfunction, poor growth, hypothyroidism and osteopenia/osteoporosis. These complications, which have been described above, arise primarily as a result of the preparatory regimen (high-dose chemotherapy and/or TBI) and may be exacerbated if primary therapy included cranial radiation, alkylating agent, steroid or antimetabolite chemotherapy $[4,45,46]$. The screening and criteria for referral to endocrinology are described above and are summarized in table 3.

\section{Conclusion}

The timely and appropriate recognition of the endocrine sequelae of childhood cancer therapy can dramatically improve the quality of life of these survivors. Parents and patients should know they have access to the latest guidelines and health education materials at $w w w$. survivorshipguidelines.org (table 4). Certainly, many questions about the endocrine late effects of childhood cancer therapy remain unanswered. Recommendations are being made in 'real time' as we continue to learn more about the nature and impact of these sequelae. The COG LTFUG are a valuable tool for the screening and detection of endocrine problems among childhood cancer survivors. It is important for endocrinologists to understand the COG screening recommendations that are used for the early detection of endocrine sequelae and the rationale for pursuing further endocrine evaluation. 


\section{Acknowledgments}

We would like to acknowledge the members of the Endocrine Task Force for the COG Long-Term Follow-Up Guidelines for their contributions to the material in this paper: Natalie Alos, MD; Laurie Cohen, MD; Kimberly Dilley, MD, MPH; Charles
Sklar, MD; Stacey Urbach, MD; Suzanne Wolden, MD; Eileen Duffey-Lind, RN; Wendy Hobbie, RN; Patricia Kent, RN, and Octavio Zavala. This writing was also supported in part by the Children's Oncology Group grant U10CA098543 from the National Cancer Institute.

\section{References}

1 Bhatia S: Cancer survivorship - pediatric issues. Hematology Am Soc Hematol Educ Program 2005;507-515.

$\checkmark 2$ Cohen LE: Endocrine late effects of cancer treatment. Endocrinol Metab Clin North Am 2005;34:769-789.

3 Marina N: Long-term survivors of childhood cancer. The medical consequences of cure. Pediatr Clin North Am 1997;44:10211042.

-4 Sklar C, Boulad F, Small T, Kernan N: Endocrine complications of pediatric stem cell transplantation. Front Biosci 2001;6:G17G22.

$\checkmark 5$ Oeffinger KC, Mertens AC, Sklar CA, Kawashima T, Hudson MM, Meadows AT, Friedman DL, Marina N, Hobbie W, KadanLottick NS, Schwartz CL, Leisenring W, Robison LL: Chronic health conditions in adult survivors of childhood cancer. N Engl J Med 2006;355:1572-1582.

6 Gleeson HK, Shalet SM: Endocrine complications of neoplastic diseases in children and adolescents. Curr Opin Pediatr 2001;13:346351.

7 Meacham L: Endocrine late effects of childhood cancer therapy. Curr Probl Pediatr Adolesc Health Care 2003;33:217-242.

$\checkmark 8$ Landier W, Wallace WH, Hudson MM: Long-term follow-up of pediatric cancer survivors: education, surveillance, and screening. Pediatr Blood Cancer 2006;46:149-158.

$\checkmark 9$ Landier W, Bhatia S, Eshelman DA, Forte KJ, Sweeney T, Hester AL, Darling J, Armstrong FD, Blatt J, Constine LS, Freeman CR, Friedman DL, Green DM, Marina N, Meadows AT, Neglia JP, Oeffinger KC, Robison LL, Ruccione KS, Sklar CA, Hudson MM: Development of risk-based guidelines for pediatric cancer survivors: the Children's Oncology Group Long-Term Follow-Up Guidelines from the Children's Oncology Group Late Effects Committee and Nursing Discipline. J Clin Oncol 2004;22:4979-4990.

10 Gleeson HK, Shalet SM: The impact of cancer therapy on the endocrine system in survivors of childhood brain tumours. Endocr Relat Cancer 2004;11:589-602.

-11 Shalet SM, Beardwell CG, Morris-Jones P, Bamford FN, Ribeiro GG, Pearson D: Growth hormone deficiency in children with brain tumors. Cancer 1976;37:1144-1148.
12 Constine LS, Woolf PD, Cann D, Mick G, McCormick K, Raubertas RF, Rubin P: Hypothalamic-pituitary dysfunction after radiation for brain tumors. N Engl J Med 1993; 328:87-94.

-13 Brownstein CM, Mertens AC, Mitby PA, Stovall M, Qin J, Heller G, Robison LL, Sklar CA: Factors that affect final height and change in height standard deviation scores in survivors of childhood cancer treated with growth hormone: a report from the childhood cancer survivor study. J Clin Endocrinol Metab 2004;89:4422-4427.

14 Costin G: Effects of low-dose cranial radiation on growth hormone secretory dynamics and hypothalamic-pituitary function. Am J Dis Child 1988;142:847-852.

15 Chrousos GP, Poplack D, Brown T, O’Neill D, Schwade J, Bercu BB: Effects of cranial radiation on hypothalamic-adenohypophyseal function: abnormal growth hormone secretory dynamics. J Clin Endocrinol Metab 1982;54:1135-1139.

16 Oberfield SE, Soranno D, Nirenberg A, Heller G, Allen JC, David R, Levine LS, Sklar CA: Age at onset of puberty following high-dose central nervous system radiation therapy. Arch Pediatr Adolesc Med 1996;150:589592.

17 Ogilvy-Stuart AL, Clayton PE, Shalet SM: Cranial irradiation and early puberty. J Clin Endocrinol Metab 1994;78:1282-1286.

18 Mills JL, Fears TR, Robison LL, Nicholson HS, Sklar CA, Byrne J: Menarche in a cohort of 188 long-term survivors of acute lymphoblastic leukemia. J Pediatr 1997;131:598602.

19 Rose SR, Lustig RH, Pitukcheewanont P, Broome DC, Burghen GA, Li H, Hudson MM, Kun LE, Heideman RL: Diagnosis of hidden central hypothyroidism in survivors of childhood cancer. J Clin Endocrinol Metab 1999;84:4472-4479.

20 Livesey EA, Brook CG: Thyroid dysfunction after radiotherapy and chemotherapy of brain tumours. Arch Dis Child 1989;64:593595.

-21 Rose SR, Danish RK, Kearney NS, Schreiber RE, Lustig RH, Burghen GA, Hudson MM: ACTH deficiency in childhood cancer survivors. Pediatr Blood Cancer 2005;45:808813 .
22 Oberfield SE, Nirenberg A, Allen JC, Cohen H, Donahue B, Prasad V, Schiff R, Pang S, Ghavimi F, David R, Chrousos G, Sklar C: Hypothalamic-pituitary-adrenal function following cranial irradiation. Horm Res 1997;47:9-16.

23 Schmiegelow M, Feldt-Rasmussen U, Rasmussen AK, Lange M, Poulsen HS, Muller J: Assessment of the hypothalamo-pituitaryadrenal axis in patients treated with radiotherapy and chemotherapy for childhood brain tumor. J Clin Endocrinol Metab 2003; 88:3149-3154.

24 Sklar CA, Constine LS: Chronic neuroendocrinological sequelae of radiation therapy. Int J Radiat Oncol Biol Phys 1995;31:11131121.

25 Oeffinger KC, Mertens AC, Sklar CA, Yasui Y, Fears T, Stovall M, Vik TA, Inskip PD, Robison LL: Obesity in adult survivors of childhood acute lymphoblastic leukemia: a report from the Childhood Cancer Survivor Study. J Clin Oncol 2003;21:1359-1365.

26 Gurney JG, Kadan-Lottick NS, Packer RJ, Neglia JP, Sklar CA, Punyko JA, Stovall M, Yasui Y, Nicholson HS, Wolden S, McNeil DE, Mertens AC, Robison LL: Endocrine and cardiovascular late effects among adult survivors of childhood brain tumors: Childhood Cancer Survivor Study. Cancer 2003; 97:663-673.

-27 Brennan BM, Shalet SM: Endocrine late effects after bone marrow transplant. $\mathrm{Br} J \mathrm{Hae}-$ matol 2002;118:58-66.

-28 Sigurdson AJ, Ronckers CM, Mertens AC, Stovall M, Smith SA, Liu Y, Berkow RL, Hammond S, Neglia JP, Meadows AT, Sklar CA, Robison LL, Inskip PD: Primary thyroid cancer after a first tumour in childhood the Childhood Cancer Survivor Study): a nested case-control study. Lancet 2005;365:20142023.

29 Sklar C: Maintenance of ovarian function and risk of premature menopause related to cancer treatment. J Natl Cancer Inst Monogr 2005;34:25-27.

-30 Howell SJ, Shalet SM: Spermatogenesis after cancer treatment: damage and recovery. J

Natl Cancer Inst Monogr 2005;34:12-17.
31 Kenney LB, Laufer MR, Grant FD, Grier H, Diller L: High risk of infertility and longterm gonadal damage in males treated with high dose cyclophosphamide for sarcoma during childhood. Cancer 2001;91:613-621. 
32 Howell SJ, Shalet SM: Testicular function following chemotherapy. Hum Reprod Update 2001;7:363-369.

33 Gleeson HK, Darzy K, Shalet SM: Late endocrine, metabolic and skeletal sequelae following treatment of childhood cancer. Best Pract Res Clin Endocrinol Metab 2002;16: 335-348.

-34 Taskinen M, Saarinen-Pihkala UM, Hovi L, Lipsanen-Nyman M: Impaired glucose tolerance and dyslipidaemia as late effects after bone-marrow transplantation in childhood. Lancet 2000;356:993-997.

-35 Teinturier C, Hartmann O, Valteau-Couanet D, Benhamou E, Bougneres PF: Ovarian function after autologous bone marrow transplantation in childhood: high-dose busulfan is a major cause of ovarian failure. Bone Marrow Transplant 1998;22:989-994.

-36 Afify Z, Shaw PJ, Clavano-Harding A, Cowell CT: Growth and endocrine function in children with acute myeloid leukaemia after bone marrow transplantation using busulfan/cyclophosphamide. Bone Marrow Transplant 2000;25:1087-1092.
37 Gerl A, Muhlbayer D, Hansmann G, Mraz W, Hiddemann W: The impact of chemotherapy on Leydig cell function in long term survivors of germ cell tumors. Cancer 2001; 91:1297-1303.

38 Sklar C: Reproductive physiology and treatment-related loss of sex hormone production. Med Pediatr Oncol 1999;33:2-8.

39 Muller J: Disturbance of pubertal development after cancer treatment. Best Pract Res Clin Endocrinol Metab 2002;16:91-103.

40 Kaste SC: Bone-mineral density deficits from childhood cancer and its therapy. A review of at-risk patient cohorts and available imaging methods. Pediatr Radiol 2004;34: 373-378, 443-374.

41 Kaste SC, Jones-Wallace D, Rose SR, Boyett JM, Lustig RH, Rivera GK, Pui CH, Hudson MM: Bone mineral decrements in survivors of childhood acute lymphoblastic leukemia: frequency of occurrence and risk factors for their development. Leukemia 2001;15:728734.

42 Raghavan D, Cox K, Childs A, Grygiel J, Sullivan D: Hypercholesterolemia after chemotherapy for testis cancer. J Clin Oncol 1992; 10:1386-1389.
43 Ellis PA, Fitzharris BM, George PM, Robinson BA, Atkinson $\mathrm{CH}$, Colls BM: Fasting plasma lipid measurements following cisplatin chemotherapy in patients with germ cell tumors. J Clin Oncol 1992;10:1609-1614.

44 Stein J, Dini G, Yaniv I: The hope and the reality of reduced intensity transplants in children with malignant diseases. Bone Marrow Transplant 2005;35(suppl 1):S39S43.

-45 Baker KS, Gurney JG, Ness KK, Bhatia R, Forman SJ, Francisco L, McGlave PB, Robison LL, Snyder DS, Weisdorf DJ, Bhatia S: Late effects in survivors of chronic myeloid leukemia treated with hematopoietic cell transplantation: results from the Bone Marrow Transplant Survivor Study. Blood 2004; 104:1898-1906.

46 Bhatia S, Ramsay NK, Weisdorf D, Griffiths H, Robison LL: Bone mineral density in patients undergoing bone marrow transplantation for myeloid malignancies. Bone Marrow Transplant 1998;22:87-90. 